\title{
Modernization and intensification of agriculture in the republic of Uzbekistan
}

\author{
N.K. Yuldashev ${ }^{1}$, V.I. Nabokov ${ }^{2}$, K.V. Nekrasov ${ }^{3, *}$, and B.O. Tursunov ${ }^{1}$ \\ ${ }^{1}$ Tashkent State University of Economics, Management department, Tashkent, Uzbekistan \\ ${ }^{2}$ Ural State Agrarian University, Department of Management and Law, Ekaterinburg, Russia \\ ${ }^{3}$ Ural State University of Railway Transport, Department of World Economy and Logistics, \\ Ekaterinburg, Russia
}

\begin{abstract}
The article shows that the desire of the Republic of Uzbekistan for food independence is largely determined by the successful implementation of measures for further modernization and intensification of agriculture in the Republic. The study showed that in recent years, the country's land use and crop production system has seen significant changes related to the structure of acreage and methods of processing grain and cotton crops. Despite the positive results, there are a number of problems hindering the development of the agricultural sector in Uzbekistan. Measures are proposed to increase crop rotation, create interconnected chains with the participation of low-power farms and the state, exportoriented production of products with additional cost, which will eliminate a number of these obstacles and increase the dynamics of the agricultural sector and transform it into a competitive industry that works in the interests of the private sector, citizens and the state.
\end{abstract}

\section{Introduction}

In the Republic of Uzbekistan today, the agricultural sector-agriculture, horticulture and vegetable growing-is developing very quickly. Intensive cotton-wheat crop rotation is widely used. More than 3 million tons of raw cotton and more than 6 million tons of wheat are produced annually.

There have been significant changes in the country's land use and crop production system recently. The main goal of the agricultural policy of the Republic of Uzbekistan is the desire for food independence of the country. For this purpose, the structure of the acreage was changed. Thus, the share of acreage under grain crops has been increased to $40 \%$. As a result, grain production exceeded 6 million tons, which is four times more than in the Soviet period, when grain resources came to the Republic from the all-Union Fund.

\footnotetext{
* Corresponding author: ekonn@bk.ru
} 


\section{Research methods}

The study of the level and dynamics of development of agricultural organizations in the Republic of Uzbekistan, factors that hinder this activity. At the same time, modern research methods were used: abstract-logical, monographic, economic-statistical, sociological, and survey. The data of official statistics, materials of the survey of heads of organizations of the agricultural sector of Uzbekistan were used.

\section{Study Details}

An attempt is being made to sustainably produce two crops from one field per year. For example, after winter wheat, rice is sown, or after spring corn, winter barley is sown. Grain crops, mainly winter and spring wheat (87\% of gross production), are cultivated almost everywhere. The main areas of rice production ( $8.3 \%$ of gross grain production) are Karakalpakstan and Khorezm region. In recent years, grain production per capita has increased in the country from $92 \mathrm{~kg}$ in 1990 to $180 \mathrm{~kg}$ in 2000.

Recently, along with the high results achieved in the agricultural sector of the country, there are also a number of shortcomings.

Thus, the frequent use of the "cotton-wheat" crop rotation on huge agricultural areas of irrigated lands has led to a decrease in the humus layer.

In the Republic, the average humus content on cultivated areas is only $0.7-1.0 \%$. moreover, there is a constant decrease in this indicator. At the same time, millions of tons of organic substances (mainly humus nutrients) are taken out, both with the crop, and with straw stalks, weeds. The use of large amounts of mineral fertilizers on soils with a humus content of $0.7-1.0 \%$ has virtually no effect on increasing the yield index. At the same time, due to the reduction in the number of livestock in the Republic, the amount of manure introduced to the fields has decreased significantly, it is lower than the total annual demand. Thus, the deficit of organic substances that are returned to the soil for the formation of humus and increase the fertility of agricultural acreage is progressing [12].

In the fields of Uzbekistan, the yield of cotton, wheat, tomatoes, potatoes and other crops is significantly lower than the potential of the agricultural sector. The growth of this indicator will not only increase the income and export potential of agricultural businesses and farms, but also create an opportunity to transfer additional areas of land currently occupied by cotton and wheat to other profitable crops.

Also, a relatively inexpensive and effective way to increase soil fertility (1-1.5 times over several years) is the use of organic fertilizers, which will increase the yield of agricultural crops by more than $12-16 \%$ [11].

Analytical studies and statistical data show that there is a large resource potential of the Republic. There are new, environmentally friendly and cost-effective technologies for producing organic and organo-mineral fertilizers.

In recent years tests have been carried out in a number of regions and new technologies of crops irrigation were recommended for application. According to corresponding state program in the Republic of Uzbekistan in 2013-2017 modern methods of land irrigation on 104600 hectares were implemented. According to the data from the Ministry of Agriculture and Water Management of Uzbekistan, drip irrigation technologies of cultivated land for 47356,0 hectares, irrigation of cultivation beds under polyethylene film for 19214,0 hectares, irrigation with the help of movable flexible pipes for 18418,0 hectares were implemented in the republic (fig. 1).

It should be noted that manure and other organic fertilizers are particularly important for obtaining high and sustainable yields of vegetable crops. 
On cultivated areas with a low humus content $(0.5 \%-0.85 \%)$, a small amount of mobile phosphorus and potassium is observed. Most areas with such humus indicators have an acidic reaction ( $\mathrm{pH} 4.5-5.5)$. Without applying the necessary amount of fertilizer to these fields, it is impossible to get a sufficiently high and stable crop from them. Manure and other organic fertilizers are especially important in increasing the fertility of these soils.

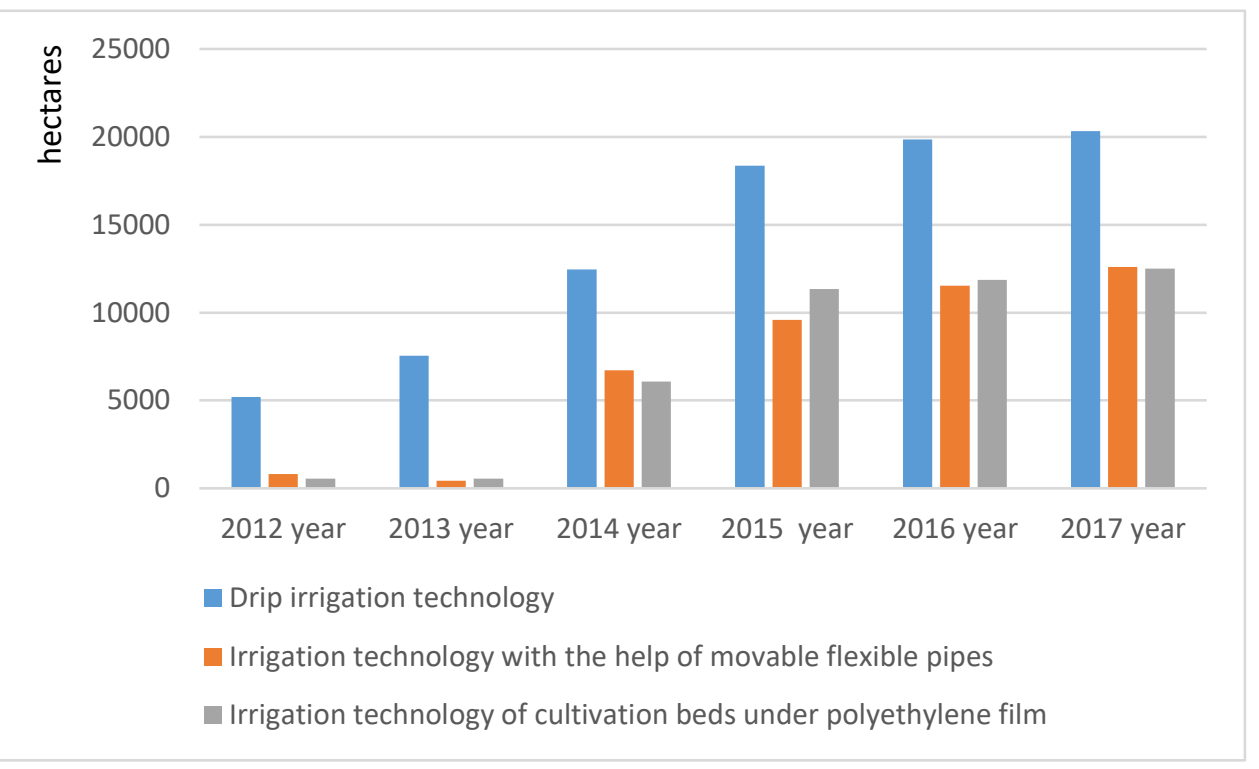

Fig.1. Planted areas of the republic where modern irrigation methods were implemented, in hectares

The value of manure and other organic fertilizers is not only that they contain all the elements necessary for the life of crops, but also that they have a significant impact on the physical and chemical composition of the soil, increase the degree of soil aeration, buffering and moisture absorption capacity, enrich the soil with microorganisms, enhancing biological activity [13].

As already noted, organic fertilizers, in particular manure, are a necessary element that affects the increase and restoration of agricultural land fertility. In this regard, it should be noted that animal husbandry in the country is also developing dynamically.

Animal husbandry is also one of the main branches of the agricultural sector of Uzbekistan, which accounts for $45.3 \%$ of agricultural products produced in the country. The main feature of the industry is that the vast majority of livestock production is produced in small family (Dehkan) farms, the average size of the occupied area of which is about 0.15 hectares.

The production of livestock products in small Dekhkan farms is of particular social importance, as it is an important source of income and consumption of products for the vast majority of families [7]. At the same time, the small size of the vast majority of livestock production leads to limited opportunities to use advanced technologies and achieve a positive effect of "economies of scale", which is manifested in the relatively low performance indicators of the industry [14].

Along with these, there are also other shortcomings in the development of animal husbandry in the country. Thus, one of the most pressing problems of animal husbandry in the country is the lack of feed, which is associated with a large-scale reduction of acreage under forage crops and a decrease in soil fertility.

Thus, it is easy to establish a logical relationship between agriculture, crop production and animal husbandry. 
Taking into account the importance of ensuring sustainable development of animal husbandry and the seriousness of the existing problems, the government of Uzbekistan is taking measures to reform the industry. The program document for this process is the Decree of the President of the Republic of Uzbekistan No. 308 of March 23, 2006 "On measures to stimulate the increase in the number of livestock in private farms, Dehkan farms and farms".

Resolution of the President of the Republic of Uzbekistan of March 5, 2016 No. PP-2505 "About measures for further development of source of raw materials, deepening of conversion of fruit and vegetable and meat and dairy products, increase in production and export of provisions in 2016-2020" provides for 180 investment projects on deep conversion of agricultural products with a total value of 595886,3 thousand dollars carrying out. (Table 1)

Table 1. Investment projects for construction, reconstruction and modernization of deep conversion of agricultural products facilities until 2020 and their financing, in thousand dollars

\begin{tabular}{|l|l|l|l|l|}
\hline Projects name & Projects cost & \multicolumn{3}{|l|}{ Including by sources of financing: } \\
\cline { 3 - 5 } & & Internal funds & Banks loans & $\begin{array}{l}\text { Foreign } \\
\text { investments and } \\
\text { loans }\end{array}$ \\
\hline $\begin{array}{l}\text { Total (180 } \\
\text { projects) }\end{array}$ & 595886,3 & 242916,7 & 189461,6 & 163508,0 \\
\hline including & & & 144324,6 & 149228,0 \\
\hline $\begin{array}{l}\text { New } \\
\text { construction (141 } \\
\text { projects) }\end{array}$ & 463267,3 & 169714,7 & 45137,0 & 14280,0 \\
\hline $\begin{array}{l}\text { Reconstruction } \\
\text { and } \\
\text { modernization } \\
\text { (39 projects) }\end{array}$ & 132619,0 & 73202,0 & & \\
\hline
\end{tabular}

This resolution provides for 138 enterprises of fruit and vegetables conversion with output of 99100 tons, 46 enterprises of meat products conversion with output of 16500 tons, 79 enterprises of dairy products conversion with output of 34850 tons, and 153 enterprises of other food products conversion with capacity of 26840 tons commissioning in 2016-2020 [3].

According to the state statistics Committee, in 2018, the Republic produced agricultural products by 192.8 trillion sums'. The state statistics Committee of Uzbekistan has officially recorded that 102.6 trillion of this amount sums, or $53.2 \%$, account for crop production, while 90.2 trillion. sums, or $46.8 \%$, are used for livestock products.

Official statistics noted that there is a division of labor between agricultural producers in the country's regions.

The results of the analysis showed that in Andijan, Namangan, Syrdarya, Samarkand, Fergana, Surkhandarya, Bukhara and Tashkent regions, the development of crop production was mainly observed. These regions account for $51.7-69.4 \%$ of crop production from the country's gross agricultural output.

The development of animal husbandry has been recorded in the Jizzakh, Navai, Kashkadarya and Khorezm regions and the Republic of Karakalpakstan. In these regions, livestock production accounts for 52.6 - 61.6\% of the gross agricultural output (Fig 2). 


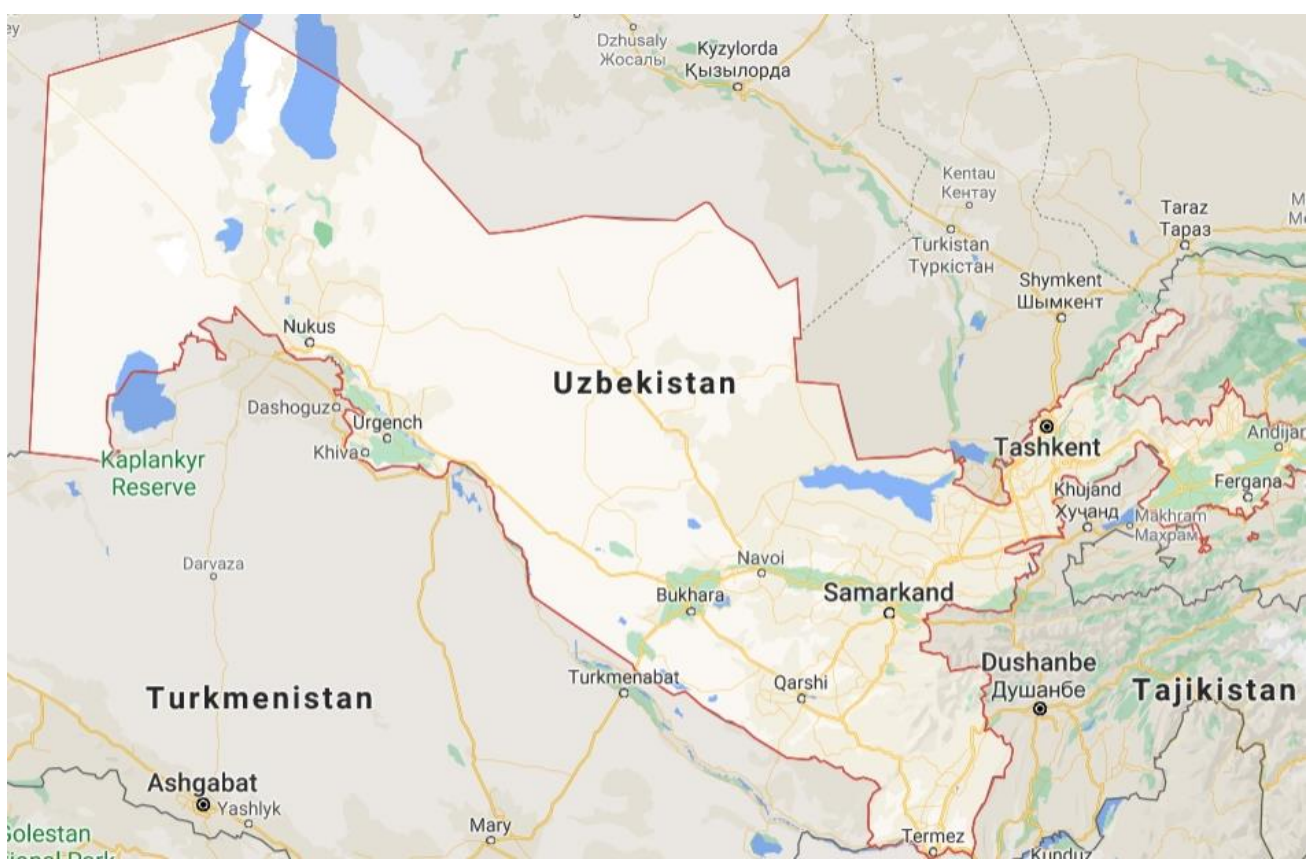

Fig. 2. Republic of Uzbekistan (source: Google maps, 40 $11^{\prime} 59.9^{\prime \prime} \mathrm{N} 67^{\circ} 49^{\prime} 32.8^{\prime \prime} \mathrm{E}$ )

There was a lag in the field of crop production compared to 2017. In 2018, all categories of farms produced $6,375,4$ thousand tons $(-12,5 \%)$ of grain crops, potatoes - 2,750,1 thousand tons $(-1,6 \%)$, vegetables $-9,635,1$ thousand tons $(-5,7 \%)$, melon food products $1,904,9$ thousand tons $(-6,2 \%)$, fruits and berries $-2,589,7$ thousand tons $(-1 \%)$, grapes $1,564,5$ thousand tons $(-3,8 \%)$.

At the same time, in 2018, all categories of livestock farms produced 2417.4 thousand tons of meat in live weight (5.7\% more than in 2017), 10480.7 thousand tons of milk (+ $4.3 \%), 7360.5$ million eggs (+ $16.2 \%), 1082.6$ thousand pieces of Karakul $(+0.7 \%)$.

As of January 1, 2019, the total number of cattle in the Republic reached 12,726. 6 thousand heads, including cows-4,522. 2 thousand heads, sheep and goats-21,287. 4 thousand heads, poultry-81,538. 9 thousand heads.

Compared to the corresponding period in 2018, all categories of farms the number of cattle increased by 255,6 thousand ( $2 \%$ ), including cows - by 185,7 thousand ( $4.3 \%)$, sheep and goats - on 646,5 thousand heads $(+3.1 \%)$, poultry - by 6668,8 thousand $(8.9 \%)$, according to the official information of Goskomstat [7].

However, it is necessary to eliminate a number of obstacles that stand in the way of dynamic development of the agricultural sector and the transformation of the industry into a competitive one that works in the interests of the private sector, citizens and the state [4].

In the previous year, about $69.7 \%$ of cultivated land in Uzbekistan was used for cotton and wheat production. A significant increase in demand for other types of agricultural products led to the fact that large-scale areas in the agricultural sector were removed from the cultivation of cotton and wheat. However, in order to get the maximum effect for the development of agriculture, it is necessary to withdraw additional areas currently used for growing these two crops, with their subsequent transfer to other, relatively profitable crops, in particular vegetables and fruits. According to the official information of the world Bank, reducing the area occupied by cotton and wheat in Uzbekistan to about $45 \%$ of the acreage will lead to an increase in gross agricultural output by $52.2 \%$, employment in the agricultural sector will grow by $17 \%$, and water savings - by $10.5 \%$. 
Thus, there is an urgent question about how to quickly transfer these lands to more profitable crops? This procedure should be implemented step by step and synchronously with changes in adjacent industries. For example, recombination of land for the production of vegetables and fruits should take place simultaneously with the improvement of agricultural statistics both within the country and at its customs borders. This will make it possible to quickly deliver perishable fruit and vegetable products from producers to end users, as well as to international markets (Decree of the President of the Republic of Uzbekistan dated October 23, 2019).

Otherwise, overproduction of vegetables and fruits will lead to a greater decrease in income than an increase in revenue from the sale of the same wheat or cotton.

The government's measures and economic reforms to join the world trade organization (WTO) will create a basis for increasing exports of domestic agricultural products, especially fruit and vegetables, to more countries.

One of the main requirements for the agricultural sector of the country is the need to ensure greater participation of labor resources in the implementation of opportunities provided by exports. Currently, the predominant volume of fruit and vegetable production is accounted for by small Dekhkan farms. Their share is more than 60 percent of gross production. However, the pace of creating an interconnected chain with the participation of low-power farms focused on the production of products with additional cost, aimed at exports, remains low [6].

The inclusion of the above-mentioned producers in such chains with the help of state programs to stimulate agriculture, cooperation of agricultural cooperatives with agribusiness, as well as with exporters would create an opportunity for the development of production potential and increase the profitability of smaller businesses in the agricultural sector.

Ignoring the existing problems of small businesses in the agricultural sector will lead to the fact that the export of agricultural products will create new opportunities only for a small group of farmers and agricultural enterprises, and an excellent opportunity for inclusive economic development of this group of farmers will be missed.

In Uzbekistan, in 2018, public spending on the agricultural sector amounted to about 1.7 $\%$ of GDP (in 2016 and 2017, these expenditures were more than $2 \%$ of GDP), when middleincome countries spend an average of $0.6 \%$ of GDP. Organization for economic cooperation and development (OECD) countries with high incomes - $0.2 \%$ of GDP. In 2018, Kazakhstan spent $0.8 \%$ of its GDP on agriculture, while Vietnam spent only $0.5 \%$. Even twenty years ago, when middle-income countries were poorer, their agricultural budgets were about $1.3 \%$ of GDP.

Even with high government spending on the agricultural sector, the domestic agricultural industry is not yet able to show high efficiency. So, in 2018, agriculture showed a slight increase.

For example, large amounts of public funds are currently allocated to cover the cost of electricity, which is necessary for pumping water to irrigate crop areas, and for operating and managing an irrigation system that delivers water to cotton and wheat producers. At the same time, very little money is spent on upgrading this irrigation and reclamation infrastructure. This means that in the short term, the government will need to spend more money on upgrading this infrastructure to serve the needs of diversified agriculture.

Uzbekistan is one of the few countries in the world where domestic prices for basic agricultural products are lower than international prices. In most States, the situation is absolutely the opposite.

The rights of small businesses in the agricultural sector of the country to land ownership are legally protected. This was one of the main reasons for a greater increase in crop yields on the sown areas of small Dekhkan farms than on larger farms, despite the fact that they 
have to pay more for material and technical resources, it is more difficult for them to mechanize production on their small land plots [5].

Also, for a number of reasons, large farmers may lose land leased from the state due to low profitability of farms. This may be due to optimization of farms, non-compliance with the crop placement plan, or non-compliance with the state plan for harvesting cotton and wheat, which is the responsibility of local authorities.

This non-modern system of control over the activities of farms is detrimental to their development. It demotivates farmers to invest in land given to them for use by local authorities. Today, there is a need to abandon this counterproductive practice on the part of the state. This was done throughout the post-Soviet space, as well as in China and Vietnam many years ago [4].

The best practices of China and Vietnam show how to reform approaches to motivating farmers. In these countries, the system of public procurement was canceled long ago, but this did not lead to the collapse of their agriculture. The production of a small number of strategic crops here is stimulated by a system of crop placement, direct budget payments to farmers, and the implementation of relevant government programs aimed at increasing yields, improving product quality, and protecting against pests and diseases. This approach differs from the existing support system and the state plan for cotton and wheat harvesting in Uzbekistan.

Until farmers are fully confident that their land rights are secure, they will not invest in increasing productivity and improving the fertility of land provided to them by local authorities [10].

Of course, the list of tasks and challenges outlined above looks quite extensive. However, their solution is seen as quite realistic and extremely necessary to accelerate the modernization and increase the competitiveness of agriculture, as well as for structural changes in the country's economy. The country is consistently implementing measures to develop the production of agricultural machinery and to provide the population with domestically produced machinery [9].

However, the coordinated cooperation between enterprises - manufacturers of agricultural machinery, a large share of imported parts in manufactured equipment, poor maintenance, lack of stable system of providing technology to the agricultural sector and the harmonisation of science and industry require special attention to this sector. The decree of the President of the Republic of Uzbekistan PP-4410 of July 31, 2019 provides for a plan of measures for the implementation of the developed investment projects to increase the production of agricultural machinery for a total of 74.9 million soums (Resolution of the President of the Republic of Uzbekistan dated July 31, 2019).

It is assumed that the agricultural sector of Uzbekistan will switch to "Smart agriculture". The Ministry of innovative development of the country puts this issue as a priority.

It is planned to solve this task by introducing innovative ideas and technologies in the agricultural sector, which will allow to automate agricultural activities as much as possible, significantly increase the yield of priority crops and improve the financial performance of enterprises. One of the ultimate goals is to ensure the country's food security.

The introduction of new techniques and technologies, such as sensors, GPS systems, big data, etc., is a fundamental link for solving these problems. The transition of the agricultural sector to digital technologies will significantly simplify the processes of management and production in it.

Thus, the use of GPS will improve the accuracy of the movement of equipment on the field, and the use of sensors-to track the state of the soil, calculate its composition in certain areas. Big data opens the way to expand knowledge about the processes that occur during crop growth. Such innovations will create conditions for the emergence of "Precision farming" technology in the agricultural sector. 
The company "Uzbekozikovkatholding" created a specialized LLC "Unmanned technologies" for the operation of unmanned systems. Last November, the company's specialists took courses on the use of "Ptero G1" unmanned aircraft systems. They will be used for measuring crops and monitoring them, which will allow timely updating of planning and cartographic materials and eliminating shortcomings in agricultural activities.

Agricultural weather stations operating on the basis of "Internet of thing" have been installed in the Yangiyul and Urtachirchik districts of the Tashkent region. They are equipped with sensors that predict the amount of precipitation, air and soil temperature, humidity, wind speed and direction.

Based on the collected data, the risk of diseases and pests, the dates of preventive soil treatment, the time and intensity of its irrigation are calculated. After the analysis, the information will be sent to gardeners and farmers on the phone in the form of recommendations about the need for agricultural activities.

This joint project of the chamber of Commerce and industry and UNDP "Business forum of Uzbekistan (phase III)" is aimed at implementing the concept of "Smart farm" and automation of farming. In the future, weather stations will be installed in two more districts of the Tashkent region.

\section{Conclusion}

In recent years, some work has been carried out in the direction of reforming the country's agricultural sector, in particular to improve the system of public administration, widely introduce market relations, strengthen the legal framework for relations between entities that produce, process and sell agricultural products, attract investment in the industry, introduce resource-saving technologies, and provide agricultural producers with modern equipment. In this regard, on October 23, 2019, the Presidential decree UP-5853 "On approval of the strategy for the development of agriculture of the Republic of Uzbekistan for 2020 - 2030" was issued (Decree of the President of the Republic of Uzbekistan dated October 23, 2019).

The National strategy for agricultural development for 2019-2030, which is currently being developed, should become a fundamental document for carrying out reforms in this sector, the World Bank Group and other international partners are ready to support them financially. Its adoption and subsequent implementation by the government will transform the above-mentioned challenges into economic opportunities for the development of the country and increase the welfare of the people of Uzbekistan.

\section{References}

1. Decree of the President of the Republic of Uzbekistan dated October 23, 2019, no. UP5853 «On approval of the strategy for the development of agriculture of the Republic of Uzbekistan for 2020-2030"

2. Resolution of the President of the Republic of Uzbekistan dated July 31, 2019, no. PP4410 «On measures to accelerate the development of agricultural machinery, state support for the provision of agricultural machinery to the agricultural sector»

3. N.I. Kovalenko Agricultural Economics with the fundamentals of agricultural markets. Course of lectures (Moscow: Association of authors and publishers TANDEM: EKMOS publishing House, 1998)

4. I.A. Minakov, N. I. Kulikov, O.V. Sokolov, Economics of agricultural industries: Textbook (Moscow: Koloss, 2004) 
5. N.E. Astashov, The organization of agricultural production. The stamp of the Ministry of agriculture (Moscow: Academic project, 2014)

6. L.A. Leonova, Organization of agricultural production. Album of visual AIDS. Vulture of the Ministry of agriculture (Moscow, LAN, 964, 2017)

7. L.V. Trukhanovich, D.L. Shchur, Personnel in agriculture: Collection of personal and production (by profession) instructions (Moscow: Finpress, 2015)

8. E.A. Petrov, V.D. Mingalev, V.I. Nabokov, Agrarian Bulletin of the Urals, 12(118), 9597 (2013)

9. E.A. Skvortsov, E.G. Skvortsova, V.I. Nabokov, P.S. Krivonogov, Regional economy, 1, 249-260 (2017)

10. V.I. Nabokov, O.A. Gretsova, Agrarian Bulletin of the Urals, 7(137), 86-90 (2015)

11. V.I. Nabokov, K.V. Nekrasov, N.V. Ziablitckaia, E.A. Skvortsov, G.A. Iovlev, V.M. Sharapova, International Journal of Advanced Biotechnology and Research, 9(3),174177 (2018)

12. N.K. Yuldashev, V.I. Nabokov, K.V. Nekrasov, Moscow economic journal, 4, 31 (2018)

13. Utkur Djanibekov, Robert Finger, Agricultural systems JUL, 164, 223-235 (2018)

14. K.V. Nekrasov, Innovative activity of processing organizations of the dairy subcomplex of the region (Yekaterinburg, 2015) 